\title{
Is the college farm sustainable? A reflective essay from Davidson College
}

\author{
Amanda Green, ${ }^{\text {* }}$ David Martin, ${ }^{\mathrm{b}}$ and Gracie Ghartey-Tagoe ${ }^{\mathrm{c}}$ \\ Davidson College
}

Submitted June 3, 2020 / Revised July 27, September 2, September 22, and October 5, 2020 /

Accepted October 8, 2020 / Published online November 30, 2020

Citation: Green, A., Martin, D., \& Ghartey-Tagoe, G. (2020). Is the college farm sustainable?

A reflective essay from Davidson College. Journal of Agriculture, Food Systems, and Community

Development, 10(1), 133-149. https://doi.org/10.5304/jafscd.2020.101.024

Copyright (C 2020 by the Authors. Published by the Lyson Center for Civic Agriculture and Food Systems. Open access under CC-BY license.

\begin{abstract}
Campus farms and gardens are proliferating across college and university campuses. While they may have unique missions, at their core those missions often include promoting student learning, campus sustainability, and strong campus-community relations. In this reflective essay, we share our perspective on the sustainability of one such farm, the
\end{abstract}

a* Corresponding author: Amanda Green, Postdoctoral Fellow, Environmental Studies, Davidson College.

Green is now an assistant professor of anthropology, Eastern Kentucky University; Keith 220, 521 Lancaster Avenue; Richmond, KY 40475 USA; +1-859-622-1646; amanda.green@eku.edu

b David Martin, Professor, Environmental Studies and Economics, Davidson College; Box 6988; Davidson, NC 28035 USA; damartin@davidson.edu

c Gracie Ghartey-Tagoe, Class of 2018, Environmental Studies, Davidson College.

Ghartey-Tagoe is now an analyst at Wells Fargo Securities in Charlotte, North Carolina; g.gharteytagoe@gmail.com

\section{Author Disclosure}

Amanda Green was and David Martin is employed by Davidson College, the college discussed in this essay. Gracie Ghartey-Tagoe is a graduate of Davidson College.
Farm at Davidson College in Davidson, North Carolina, to encourage other analysts to similarly assess the interactions among these missions and sustainability's environmental, economic, and social pillars. We particularly emphasize the factors influencing the Farm's social sustainability, including the institution's pedagogical mission, treatment of

\section{Author Note}

Portions of this paper were originally written by Gracie Ghartey-Tagoe as part of her undergraduate capstone thesis in Environmental Studies at Davidson College. The capstone was supervised by her co-authors on this paper, David Martin and Amanda Green.

\section{Funding Disclosure}

Amanda Green's postdoctoral position and research at Davidson College were funded by the Duke Endowment. Gracie Ghartey-Tagoe and David Martin received funding support from the Duke Endowment to attend a conference where portions of this research were presented.

\section{Acknowledgments}

We are indebted to Farm Manager Theresa Allen, Director of Facilities David Holthouser, Facilities Business Director Leslie Urban, and Dining Services Director Dee Phillips for their support of this project. Relevant portions of this study were approved by Davidson College's Human Subjects Institutional Review Board. 
farm labor, impact on the local food economy, and equitable provision of food for students. We find that the Farm administrators misconstrue "economic" sustainability as "financial" independence and profitability. This hampers the social mission of equitably supplying students with the farm's food and offering curricular and extracurricular enrichment. We suggest ways forward that help administrators recognize the diverse values that fulfillment of additional social and environmental missions might provide, beyond direct revenues. We conclude with recommendations for institutions interested in pursuing a similar sustainability assessment of their campus farm or garden.

\section{Keywords}

Sustainable Agriculture, College Farms, Pedagogy, Sustainability, Environmental Education, Social Sustainability, Higher Education

\section{Introduction}

Over 300 campus farms and gardens, ranging in size from less than one acre to thousands of acres, have been created outside of the traditional landgrant institutions (LaCharite, 2016). The majority (87\%) were started after 2001 (LaCharite, 2016), primarily driven by student and faculty interest in enhancing environmental sustainability, community engagement, and food security within and beyond their home institutions (Hoover \& MacDonald, 2017). These farms and gardens were thus created to promote sustainability efforts on campus, to build links between the university and surrounding community, and to improve student learning through hands-on practice and interdisciplinary thinking (Hilimire, Gillon, McLaughlin, DowdUribe, \& Monsen, 2014). While teaching farms on college and university campuses are not new, the emphasis on sustainability, including economic, environmental, and social sustainability, as well as the contributions to emerging local food movements, is relatively new and serves as an important motivator to establish these farms for school administrators, faculty, staff, and students (Barlett, 2011; LaCharite, 2016; Sayre, 2011). Along with pursuing these missions, the farm must also meet a specific budgetary demand that it not create an additional burden on the college's operational budget (Holthouser \& Terry, 2012). In this reflective essay, we evaluate how well the Farm at Davidson College in Davidson, North Carolina, meets its mission to promote sustainability, connect with the community, improve student learning, and meet financial goals. Our analysis serves the larger goal of providing a template for other schools wrestling with the difficult task of evaluating these multifaceted missions.

The difficulty associated with pursuing these varied goals has been evident since the Farm's founding. The Farm was created so that the college's Dining Services could serve students the "local and organic food" they had been advocating for since the 2000s (Holthouser \& Terry, 2012, p. 1) with the following stipulations: the Farm should be a stand-alone, auxiliary business unit, "[causing] no additional burden to the college's operational budget" nor "additional burden on the operating budget of Dining Services, nor the price of meals"; the Farm should not detract from the local food market; the Farm should enhance the ability of other local vendors to sell to Dining Services; the Farm's produce should not compromise the quality and safety of food from Dining Services; the Farm should be a resource for student curricular and extracurricular activity; and the Farm should be a positive marketing tool for Dining Services and the college (Holthouser \& Terry, 2012, p. 2). It is worth noting that the goals for the Farm to operate independently and to add no burden to the college's operational budget are explicitly financial, highlighting the emphasis Davidson College placed on the financial independence of the Farm rather than its overall sustainability. While perhaps more directly stated than at other campuses, these varied goals reflect common concerns across many campus farms as their managers and partners try to evaluate their respective challenges and successes (LaCharite, 2016; Sayre, 2011). Consequently, we intend that the example of the Farm be illustrative of the sometimes-contradictory set of operating goals and broader sustainability criteria used to answer the guiding question, is the college farm sustainable, and, if not, what aspects need to be improved?

We evaluate the Farm's sustainability within the context of the traditional triad of environ- 
mental, social, and economic sustainability, commonly described as the three pillars of sustainability or the triple bottom line (Elkington, 1998; World Commission on Environment and Development, 1987). Historical analyses of sustainable development ignored the pillar of social sustainability and its primary focus on human well-being, accessibility, and equity (Jacobs, 1999). Similarly, sustainability analyses of agriculture initially largely ignored issues of social justice (Allen, Van Dusen, Lundy, \& Gliessman, 1991; Altieri, 1988). Beginning in the 1980s, Allen and co-authors (1991) encouraged scholars and activists not to assume that environmentally friendly agricultural production (such as organic practices) were synonymous with sustainable agriculture. Rather than assuming that environmental benefits will naturally result in social benefits, they advocated that a sustainable agriculture was one that equally accounted for environmental, economic, and social relationships (Allen et al., 1991). In a more recent survey of campus sustainable agriculture projects, Barlett (2011) identified campus commitments to both environmental and social sustainability; however, environmental commitments outnumbered social commitments. Indeed, Pothukuchi's (2012) sustainable food systems case study illustrated universities' bureaucratic tendency to evaluate sustainability programming using the single economic bottom line rather than the multiple (and competing) bottom lines. This reflective essay concludes with a focused discussion on historically neglected social elements of sustainability for farms in the higher education setting. These elements include the pedagogical relationships that connect campus farms to students and teachers as well as the food justice relationship that determines who has the right to eat a college farm's food.

\section{Methods}

This reflection emerges from our collaborative teaching, research, and advocacy. David Martin, an economist, is a founding member of Davidson's Environmental Studies department, a faculty representative to the Associated Colleges of the South Faculty Environmental Studies working group, and one of Davidson's faculty liaisons to the Duke Endowment, the foundation that funded the start- up costs for the Farm. He collaborated on crafting a postdoctoral position at the Farm focused on evaluating the Farm's sustainability through research and teaching. Amanda Green, a cultural anthropologist, filled the postdoctoral position from 2016 to 2018. Green designed and taught the course, "Food and Sustainability: An Introduction to the Farm at Davidson," where students volunteered at the Farm while learning about food systems and sustainability. Martin served as Green's faculty mentor, and Gracie Ghartey-Tagoe completed an Environmental Studies undergraduate capstone under their mentorship. Given our training as social scientists, we have tended to focus on the social science data at the expense of the natural sciences and humanities data. Additionally, we are advocates for college farms, thus potentially biasing our reflection to overemphasize the positive attributes of college farms.

Our analysis is written post hoc, as a reflection using the case study approach described by Yin (2009) and elaborated in the food justice setting by Porter (2018). We did not initially set out to evaluate the sustainability of the Farm with a clear set of indicators. Instead, we gathered myriad empirical data from multiple sources that enabled us to evaluate the sustainability of the Farm and offer a set of analytic tools for other universities to consider. We conducted background interviews with Davidson faculty, staff, and students, including the Farm manager, five Farm work-study students, directors of Dining Services and physical plant, and faculty that use the Farm as a resource for teaching and research. We carried out a qualitative assessment of the "Food and Sustainability" course by examining students' journals to determine the Farm's contribution to student learning (Green, 2021). The Farm's accounting books were used to analyze the Farm's finances. Because we must protect the privacy of the one full-time employee of the Farm, we discuss the finances in general terms. Additionally, Davidson Environmental Studies faculty Brad Johnson, a geologist, aided us in our evaluation of soil erosion through the soil pits he maintains in and around the Farm. Thus, in our reflection, we pull qualitative data from interviews and course assessments as well as quantitative data from the Farm's accounts and production practices. 


\section{The Davidson-Specific Context}

The Farm was established in 2012 on a historic 109-acre (44-hectare) cattle farm that was contiguous to the Davidson campus. The Farm operates on two acres (0.8 hectares) and includes two 96foot long high tunnels and a 42-foot long greenhouse. One full-time manager oversees the Farm with the assistance of between four and eight parttime Davidson students whose wages are supported by federal work-study funds, as well as two fulltime summer student interns. The Farm, according to its promotional materials, focuses on the production of "fresh, naturally grown, local produce" (Davidson College, n.d.-a)

With regard to production practices, the Farm grows a diversity of plants, utilizing rotational cropping and seeds that are certified organic, nonGMO, and/or open-pollinated. Rather than using synthetic fertilizers or pesticides, the Farm uses lime and other USDA-approved organic fertilizers to adjust the soil's $\mathrm{pH}$ and fertility. Gasoline-powered plowing and tilling are used to prepare fields and beds, but the Farm is small enough that no mechanical devices are used for planting or harvesting.

The primary crops are seasonal vegetables and fruits. During the winter season, when school is in session, the Farm focuses on the production of greens including lettuce mix, arugula, spinach, and kale for the college's Dining Services. It also raises tomatoes, peppers, eggplant, cucumbers, beans, okra, zucchini, basil, melon, strawberries, and blueberries in addition to storage crops like carrots, beets, potatoes, and sweet potatoes. The produce is sold to Dining Services, a weekly farm stand, and a 40member community supported agriculture (CSA) program, all of which are available only to Davidson students, faculty, and staff.

\section{Sustainability Analysis}

We use a Venn diagram of the sustainability triad (Figure 1) to guide our reflection on the Davidson College Farm and to generalize our approach to a broader analysis of the sustainability of campus farms. We examine the Farm's sustainability efforts through the lens of each criterion (environmental, economic, and social) and their interrelationships. Our measures of sustainability, diagrammed in Figure 1, include greenhouse gas emissions, soil erosion, cropping practices, labor practices, sources of revenue, expenses, impacts on the local food economy, pedagogical contributions, and student food access. Our selection and presentation of sustainability measures arose from a combination of the Farm's operational goals and practices as well as established guidelines for assessing sustainable agriculture (Food and Agriculture Organization of the United Nations [FAO], 2014). Through addressing these measures and their interrelationships, we highlight the need for interdisciplinary analyses of college and university farms in general. We conclude that sustainability analyses

Figure 1. Measures of Sustainability for the Farm at Davidson College

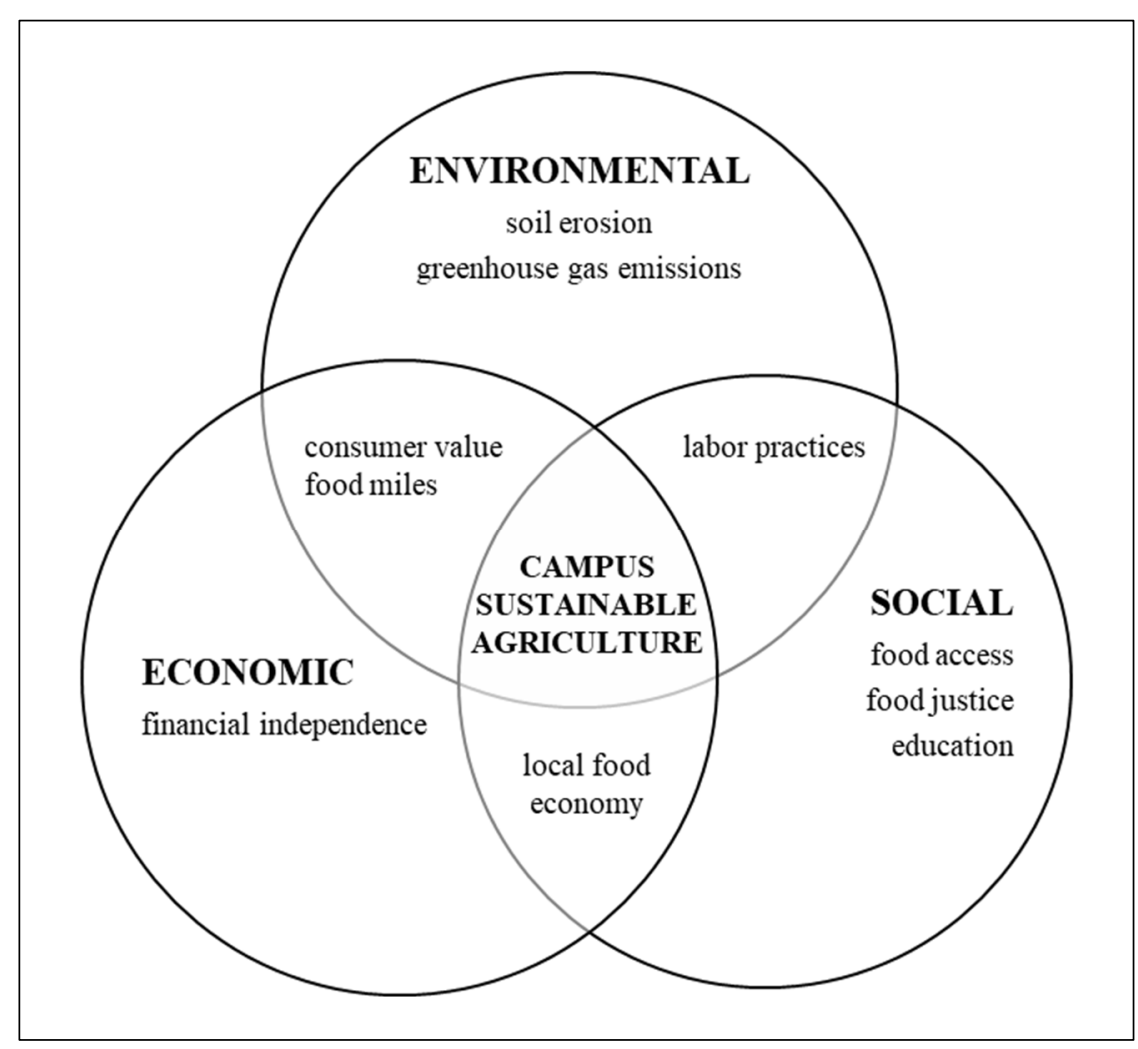


of farms in higher education must provide a richer and more holistic assessment than a simple financial spreadsheet or an environmental checklist.

\section{Environmental Analysis}

\section{Soil Erosion and Greenhouse Gas Emissions}

Given that each branch of the sustainability triad is not independent, we separate our discussion of environmental sustainability into two components. In this section we focus on aspects that one might consider "scientifically measurable" in the natural sciences. We rely on soil erosion as well as savings on greenhouse gas emissions as our primary indicators, though other metrics could be applied such as measures of soil health; water conservation; diversity of insects, plants, and animals; and cropping practices.

Given the documented shortcomings of organic standards and certifications to meeting the criteria of sustainable agriculture (Allen \& Kovach, 2000; DeLind, 2000; Guthman, 2004; Jaffee \& Howard, 2010), it is important to assess if the Farm's production processes are consistent with environmental sustainability. Historically, organic production was built upon several philosophies that include environmental and social concerns. When the 2002 USDA organic standards were introduced, scholars and activists were critical that "organic" had come to connote only the "absence of chemical residues" rather than a larger set of sustainability ideals (DeLind, 2000; Jaffee \& Howard, 2010). In our background interviews, Farm staff and administrators often cited this definitional weakness of organic combined with the cost of organic certification as the reason for why the Farm at Davidson College is not certified organic. Instead, the Farm plants seeds that are certified organic, non-GMO, and/or open-pollinated and utilizes only non-synthetic fertilizers, lime, and pesticides. In addition, the Farm grows a diversity of fruits and vegetables (as opposed to monocropping) and utilizes rotational planting to maintain soil fertility and reduce pests (T. Allen, personal communication, August 4, 2016).

However, rather than utilizing a no-till approach (Coleman, 1989) or draft animals for plowing as other schools do (e.g., Warren Wilson
College Horse Crew, 2017), the Farm relies on tractor cultivation for the preparation of new fields and beds, which can contribute to soil erosion and the loss of soil fertility (Montgomery, 2007). Soil erosion in the Davidson region appears to have begun in the 1780 s, plus or minus 20 years (Spell \& Johnson, 2019). This erosion not only caused significant gullying in the region (Ireland, Sharpe, \& Eargle, 1939; Sutter, 2015), but also resulted in a nearly total loss of the region's A horizon (i.e., top soil) (Trimble, 1972, 2008). The grazing and haying that the Farm's subsequent owners practiced may have improved the soil by allowing organic material to build back into the A horizon. However, because the Farm practices plowing, which increases the rate of organic breakdown, this historic impact is likely eliminated (B. Johnson, personal communication, January 7, 2020). Thus, there is some topsoil erosion associated with the plowing, but we lack adequate measures of it to definitively determine the Farm's impact on soil erosion and soil fertility.

The use of a tractor also releases greenhouse gases, a known contributor to climate change. According to research conducted by Kramer, Moll, and Nonhebel (1999) and cited by Cooper, Butler and Leifert (2011), plowing generates 131.6 kilograms of carbon dioxide equivalents per hectare $\left(\mathrm{kgCO}_{2} \mathrm{eha}^{-1}\right)$, which translates to 0.053 metric tons of carbon dioxide per acre. Using US\$62 as the social cost of a metric ton of carbon dioxide released into the environment (Interagency Working Group on the Social Cost of Greenhouse Gases, 2016), we estimated that the Farm costs society US $\$ 3.30$ per acre or US $\$ 6.60$ in total as a result of its use of the tractor. So, in sum, the Farm produces some localized soil degradation and a small social greenhouse gas cost. Most of the production practices on the Farm roughly offset the operation's contributions to soil erosion and greenhouse gas emissions.

\section{Food Miles and Labor Practices}

Here we turn to the components of environmental sustainability that are more directly related to social sustainability, specifically the presumed sustainability of local food. The Farm was created in response to students' growing interest in consuming 
local and organic food. While that motivating factor is important to document, it is equally important to note that these two labeling criteria may not indicate that the food was produced sustainably, and, as we stated in the introduction, social factors have often not been the focus of sustainability analyses of agriculture.

Although there is no set definition for "local," the Farm fits into the mold of local food as defined by geographic location (Lev, Hand, \& DiGiacomo, 2015; Martinez et al., 2010). The Farm's produce travels only two miles (3.2 kilometers), directly from the Farm to Dining Services. The framework of food miles, the estimated distance between where food is grown and where it is ultimate consumed, is relevant for determining if reducing the travel of certain foods results in a reduction in greenhouse gas emissions (Pirog, Van Pelt, Enshayan, \& Cook, 2001). It is also relevant when determining if locally produced food encourages shoppers to walk, bicycle, or drive fewer miles to purchase foods that they would have purchased anyway. In the case of the Farm, some of the produce is sold at a price premium through the farm stand and CSA on campus, suggesting that the combination of convenience and purchasing high-quality food offsets the higher price, which is consistent with previous research (Katt \& Meixner, 2020). Without data from customers, we cannot ascertain to what extent convenience and quality are driving those purchases. Hamilton and Hekmat (2018) concluded that Brescia University College (a Canadian women's liberal arts college) students would be willing to pay a small premium for the organic versions of individual food items such as yogurt and tomatoes. Consequently, it is fair to assert that some portion of the Farm's sales on campus are resulting in more sustainable consumer behavior consistent with the concept of "local" food.

Yet, as is well documented in the literature on the "local trap" (Purcell \& Brown, 2005), there is a distinction between "local food" and "sustainability” (Hinrichs, 2000; Hinrichs, Kloppenburg, Stevenson, Lezburg, Hendrickson, \& DeMaster, 1998). Indeed, it is now recognized through life cycle analysis that a reduction in food miles does not necessarily mean that the food is more environmentally sustainable (Pirog et al., 2001; Weber \& Matthews, 2008) or nutritious (Frith, 2007). Local economies may grow unequally and may increase local-scale inequality (Hinrichs, 2000), and therefore management of agricultural labor at the local scale is not necessarily more socially just (Gray, 2013). In contrast to the scholars and activists who have confused a means (localizing the food system) with the desired outcomes (promoting environmental, social, and economic sustainability), Born and Purcell (2006) and Kleppel (2014) emphasize assessing the results of the production process that transforms the seed into food. Consequently, beyond analyzing food miles and the transformation of seed into food, analysts of the sustainability of college and university farms need to address the critical social aspects of the production process in the assessment of social sustainability, in particular the relationship of the farm with its laborers. Analysis of a farm's labor practices may best fit within the pillar of social sustainability, but to maintain the integrity of our discussion of local food and sustainability we include labor practices herein.

To be sustainable, a farm should ensure the livelihood security and health of its workers, which includes providing a living wage, overtime pay, rest time, and paid leave (FAO, 2014). The Farm has two types of employees: the farm manager and college students. The farm manager is paid a salary per the requirements of Davidson College and is entitled to the same benefits and rights of all fulltime employees as required by U.S. law (e.g., employee-sponsored health insurance and paid sick leave), which is above and beyond what most U.S. agricultural laborers are guaranteed (or not) in U.S. agricultural labor laws (Rodman et al., 2016; U.S. Department of Labor, 2020). Students work at the Farm through the Federal Work-Study program during the fall and spring semesters or are hired as summer interns through grant-supported initiatives. The work-study students have a fixed number of hours they should work each week as part of their financial aid package, and they do have some flexibility in choosing their work-study assignment. Most summer interns are contracted to work 40 hours per week with the number of weeks spent working dependent upon the specific funding 
source. In all cases, the minimum student hourly wage is US\$7.50 (Davidson College Human Resources, n.d.), a bit above the North Carolina minimum wage of US\$7.25 (North Carolina Department of Labor, n.d.) but below the (admittedly overestimated) average wage of US $\$ 11.78$ for crop production workers in North Carolina (Department of City \& Regional Planning Master's Workshop, 2014). This figure of US $\$ 7.50$ is well below the estimated living wage of US $\$ 12.83$ for the Charlotte region (Living Wage Calculator, n.d.). In our background interviews on the challenges and benefits of working at the Farm, many work-study students reported feeling frustrated that they earned such low wages for intensive labor, particularly when other work-study students were paid the same amount for less physically demanding jobs that also allowed them to study. Simultaneously, all work-study students enjoyed their positions and felt that they gained significant personal and career benefits. Finally, the farm manager, student workers, and volunteers have access to a fully functioning toilet, running water, rest breaks, and shade, unlike many U.S. agricultural workers (Gray, 2013; Holmes, 2013). They are also not exposed to nonorganic pesticides, herbicides, and fertilizers.

Therefore, we conclude that the Farm meets sustainability criteria for its reduction in food miles and its ethical working environment. Although the work-study students could be paid a better hourly wage, that wage decision is prescribed by college policies and is not under the control of the farm manager. While one might dismiss the significance of this assessment due to the Farm's small size and hence small impact in the food system, it is significant that college farms serve as a counter-model to the labor practices that many farmworkers experience. This feature fits directly into the Farm's educational contribution, which we discuss under the aspects of social sustainability, as well as the Farm's financial sustainability, which is impacted by the fair wages paid to our farm manager, bridging the social and economic nexus we discuss next.

\section{Economic Analysis}

To measure the Farm's economic sustainability, we rely on the Farm's financial performance, its economic value to consumers, and its impact on the local food economy. Younger college and university farms are "likely to aim for financial selfsufficiency as a rationale for their continued existence" (Sayre, 2011, p. 13). Younger student farms will pursue donor funding and create a diversified market portfolio that includes direct sales through farmers markets, farm stands, and CSAs, and intermediated sales through dining halls. The Farm fits the description of a young operation, as it was established on farmland that the college had purchased four years earlier and, in 2012, the Duke Endowment funded the startup costs needed to establish farming operations. Furthermore, like younger farms, the Farm is intended to be financially self-sustaining so that it does not add to the College or Dining Services budget (Holthouser \& Terry, 2012, p. 2).

\section{Financial Independence}

The two primary operating expenses for the Farm have been the salary and benefits of the farm manager. After removing these expenses, revenues have exceeded those remaining operating costs by a growing amount annually. Still, as currently structured, the Farm is not financially sustainable because it cannot operate without a full-time manager.

The real question is whether the total economic value exceeds total costs, and that measure of economic value includes incremental value gained by the students, faculty, and staff who eat the Farm's produce. Bruno and Campbell (2016) made an important methodological advance by analyzing whether students at the University of Connecticut (a large land-grant university) would be willing to pay more for their meal plan in order to consume organic and local food. They found that $50 \%$ of their survey respondents with meal plans would be willing to pay more to have organic food options, and, similarly, $50 \%$ of their survey respondents with meal plans would be willing to pay more to have local food options available. Those University of Connecticut respondents with meal plans were willing to pay small premiums for the organic and local food options of US $\$ 42$ and US $\$ 35$ per semester, respectively (Bruno \& Campbell, 2016).

Because all enrolled Davidson College students 
must purchase a meal plan, the Farm could break even financially if all students were required to pay an annual premium to Dining Services of less than US $\$ 20$ for the Farm's food. Requiring payments for food that one does not value is not the same as asking how much one would be willing to pay for local and/or organic food. Nevertheless, we assume that the price premium for Davidson College students is likely within range of the values reported for the University of Connecticut respondents, as they are demographically similar student populations. Thus, it might be the case that the incremental value of the Farm's produce does exceed its costs; so, operating the Farm at a financial loss would be the rational economic choice.

Consequently, the economic sustainability of the Farm is an open, empirical issue. If a follow-up analysis did determine that the small premium individual students would be willing to pay would cover the remaining costs, then there are genuine managerial issues for the college to consider.

Although we need to respect privacy concerns, we can say that the Farm's operating costs have been rising because the farm manager's salary and benefits have been increasing due to the increasing longevity of tenure. However, the Farm's revenues have still been increasing faster than its operating costs, and, as such, the annual losses have been decreasing. In the analysis of Farm revenues, we found, first, that the absolute level of sales to and the percentage of revenues earned from Dining Services has decreased annually. Second, the revenue growth is a result of the Farm broadening its market channels to include sales through the farm stand, CSA, and local coffee shop that operates on campus.

Such market broadening is exactly what many would recommend to a small farm that seeks to improve its resilience and reduce its vulnerability by relying on a diversity of buyers and streams of income (FAO, 2014; Matteson, 2017). Indeed, our farm manager insightfully identified an optimal point in financial sustainability by combining production for both direct sales and intermediated markets. To maximize revenues through the CSA, farm stand, and coffee shop, the farm manager has grown a wide variety of fruits and vegetables in order to meet consumer interest and accomplish season extension and rotational cropping, as recommended by small-farm guru Eliot Coleman (1989). Additionally, the farm manager continued sales to Dining Services, so she also specialized in salad greens by growing a variety of lettuces that allowed her to accomplish year-round production (e.g., winter and summer lettuces) and effective crop rotations (Coleman, 1989). Our primary concern, however, is the observation that sales to Dining Services have declined while direct sales have increased, thus shifting the consumer base from all students to those students, faculty, and staff willing to pay for the Farm's food, which we discuss with regard to social sustainability. We conclude that the Farm's shifting customer focus appears to be consistent with economic sustainability if it is to be considered an independent economic entity. Yet, and consistent with our theme of emphasizing the social aspect of sustainability, this broadening of revenue channels needs to be viewed from the social sustainability criteria lens as well.

\section{Local Food Economy}

As we noted in the introduction, the social aspects of sustainability need greater emphasis in the missions, operations, and assessments of many campus farms (Aftandilian \& Dart, 2013; Barlett, 2011; Chollett, 2014; Galt et al., 2013). To measure one aspect of the Farm's social and economic impact on the surrounding food system, we reflect on the Farm's influence on the local food community. We begin our analysis by turning to one of the Farm's explicit goals, that it "should not detract from the local food market" (Holthouser \& Terry, 2012, p. 2). That goal arose from the recognition that, historically speaking, the Davidson region is an agricultural area (even as Charlotte's suburban sprawl continues in this area). Many of our immediate neighbors are farmers, including approximately 216 in our county of Mecklenburg (of which 11 operate direct sales) and over 2,000 in the nearest surrounding counties (USDA, 2017). Further, the college did not want to be perceived as exploiting its nonprofit status to undercut the prices its neighbors might charge, reflecting a common trend among campus farm operations (Sayre, 2011). 
The Farm's financial losses have been decreasing as sales through the Farm Stand, CSA, and coffee shop increase, and these might detract from sales by neighboring farmers. Although the Farm limits its direct sales to college students and employees only, those same students and employees might be shifting their purchases of at least some products away from the town of Davidson Farmers Market and our neighbors' farms. For example, CSA data indicate that those who participate in the Farm also participate in the Davidson Farmers Market (Green, Hunt, \& Orner, 2018). However, from student observations, it appears that other farmers do not see the Farm as a threat (Green et al., 2018). Still, there is an opportunity to extend the research at Davidson College to address such questions as saturation or opportunity in the local food system and perception of the Farm within the regional food system.

In recognition that Dining Services had not been buying any food locally for some time, the college added the goal that "the labor, logistics, and economic resources of the Farm shall strive to enhance the ability for external local vendors to incorporate more products into the Dining Service operation" (Holthouser \& Terry, 2012, p. 2). In short, the college believed that collaborating with the Farm could serve as a learning experience for Dining Services so that it could then purchase and serve other farms' local produce. However, Dining Services does not yet purchase food from other local sources and the Farm is not assisting other local farmers in selling their produce to the college (D. Holthouser, personal communication, March 14, 2018). Given the complexities involved with managing dining services in schools, we view the good-faith efforts of all parties as a positive signal. However, due to the possibility that the Farm may be competing with other local food providers and Dining Services is not purchasing from other local food providers, this measure of social and economic sustainability is not met at this time.

\section{Social Analysis}

\section{Education}

A critical nexus exists between the social and economic pillars of sustainability and a second critical nexus exists that links all three pillars. First, linking the social and economic pillars, Davidson College formally recognized that the Farm should be a resource for curricular and extracurricular activity (Holthouser \& Terry, 2012, p. 2). The pedagogical value of the Farm may be substantial. The Environmental Studies department offered the interdisciplinary course "Food and Sustainability" to introduce students to the Farm using the framework of sustainability. An assessment undertaken in this course sought to understand if volunteering at the Farm improved students' knowledge of sustainability and the food system as well as if it strengthened students' commitment to acting sustainably and transforming the food system, using frameworks established by Aftandilian and Dart (2013), Hilimire and co-authors (2014), and Meek and Tarlau (2016). We found that students became much more knowledgeable about sustainability, including about their own positions in the food system, food systems stakeholders, sustainable agriculture practices, and the competing sustainability demands within food systems (Green, 2021). These hands-on learning experiences, combined with a critical food literacy approach (Yamashita \& Robinson, 2016), made visible the challenges of creating sustainable food systems.

The linkage between the economic and social pillars arises because many colleges and universities currently frame the financial considerations of their academic activities in terms of the impacts on employee salaries and benefits (Ehrenberg, 2012). At Davidson, administrators consider, for example, if it makes more sense financially to spend academic funds to build a new computer lab or hire one new professor of economics or, perhaps, some administrative assistants. More specifically, the operating loss that the Davidson College Farm sustained in fiscal year 2016-2017 was 40\% of the median salary of a Davidson College assistant professor in fiscal year 2015-2016 (Davidson College Faculty Committee on Professional Affairs, 2017). Given that Davidson faculty teach five courses each academic year (and ignoring all of their other professional commitments), that annual loss can be framed as being equal to the teaching of two classes a year. The Farm's annual loss could also be framed in terms of four courses per year if one argued that 
the appropriate measure should be in terms of hiring adjunct faculty on a per-course basis.

Thus, within the context of the overall college budget, the social considerations involved with pedagogy are already routinely linked to the economic pillar of sustainability. We simply argue that this questioning should be extended to the context of college farms when they, like at Davidson, are housed outside of the academic budget (in the physical plant budget) but have a measurable impact on student learning. For example, in the same way that the college Physical Plant charges the Academic Affairs Office for various services, it could charge the Academic Affairs Office for the pedagogical services that the Farm offers, thereby making the economic assessment of the social contribution explicit. While we believe that the pedagogical contributions of the Farm are worth the costs expressed in terms of faculty services, the more general point is that this mechanism would make the nexus between the economic and social pillars clearer to college officials. Therefore, more studies like this that focus on the unique contributions of school farms to student learning would buttress the argument that school farms contribute positively to sustainability from a pedagogical perspective.

\section{Food Access and Food Justice}

The nexus that brings together all three sustainability pillars relates to the Farm's cropping patterns. The Farm does not monocrop but instead raises a diverse mix of crops that generate revenue and serves both the customers at the farm stand, CSA, and coffee shop as well as customers at the college's Dining Services. Those benefits are positive indicators of the Farm's sustainability.

However, shifting production to direct sales and charging a price premium may result in some students being unable to afford the food, particularly the $51 \%$ of students who are receiving financial aid at Davidson College (Davidson College, n.d.-b). Thus, by meeting one social objective and working toward its financial goal, the college is missing the opportunity to address a legitimate food justice issue through serving its own Farm's produce to students who would otherwise be unable to afford it. Food justice is critical in farm- to-school movements (Gottlieb \& Joshi, 2010) with its focus on racial and economic disparities in the production, distribution, and consumption of healthy and sustainably produced foods (Alkon \& Agyeman, 2011). Across college campuses, food insecurity negatively affects students' dietary health, learning experience, and mental well-being (Henry, 2017; Silverthorn, 2016). Colleges and their farms and gardens are uniquely positioned to provide equitable food access for all students (Dubick, Mathews, \& Cady, 2016), and in Davidson's case, due to the mandatory meal plan, the dining hall is the most equitable access point.

\section{Discussion}

Separating the definition of sustainable agriculture into its individual elements permits useful, incremental analyses of college farms, and it allows one to be certain that all of the necessary components are evaluated. The ultimate step is to determine if their combination, including interactions, "equitably balances concerns of environmental soundness, economic viability, and social justice" (Allen et al., 1991, p. 37). At the same time, there are important overlaps between the three traditional pillars of sustainability that are critical to a sustainability analysis, particularly in the social pillar. We return to a Venn diagram of the sustainability triad (Figure 2) to guide our concluding reflection.

Beginning at the top of the diagram with the "pure" environmental pillar, the Farm's environmental impacts were minimal due both to the Farm's small size and the balance it struck between sustainable cropping practices and unsustainable tractor cultivation. Economically, our findings illustrate that the Farm is not financially sustainable because revenues are less than operating costs. Yet, when moving to the intersection between the environmental and economic pillars, the perceived "local" and "organic" value consumers gained from consuming the Farm's produce exceeds its costs. In terms of the social and economic overlap, our findings indicate that the Farm has not yet succeeded in integrating local farms into the college's Dining Services operations and may be competing with local farms for customers. Finally, at the intersection of the social and environmental pillars, our findings show that the Farm is operating sustain- 
ably for a number of reasons: (1) the Farm is proximate, or local, to the college; (2) faculty, staff, and students are substituting by purchasing the Farm's produce instead of nonlocal crops; and (3) the Farm is treating its locally hired laborers fairly, with the exception of low hourly wages for students. In conclusion, our assessment has revealed that the Davidson College Farm is benign with respect to sustainability.

Yet, this analysis ignores two critical components noted in Figure 2: "pedagogy" and "cropping." Both components merit special attention at Davidson and at other colleges and universities with farms.

We turn first to cropping. At the Davidson Farm, this aspect concerns whether the farm manager should plant and harvest diverse crops for the most profitable market channels or plant and

\section{Figure 2. The Sustainability Interrelationships of the Davidson College Farm}

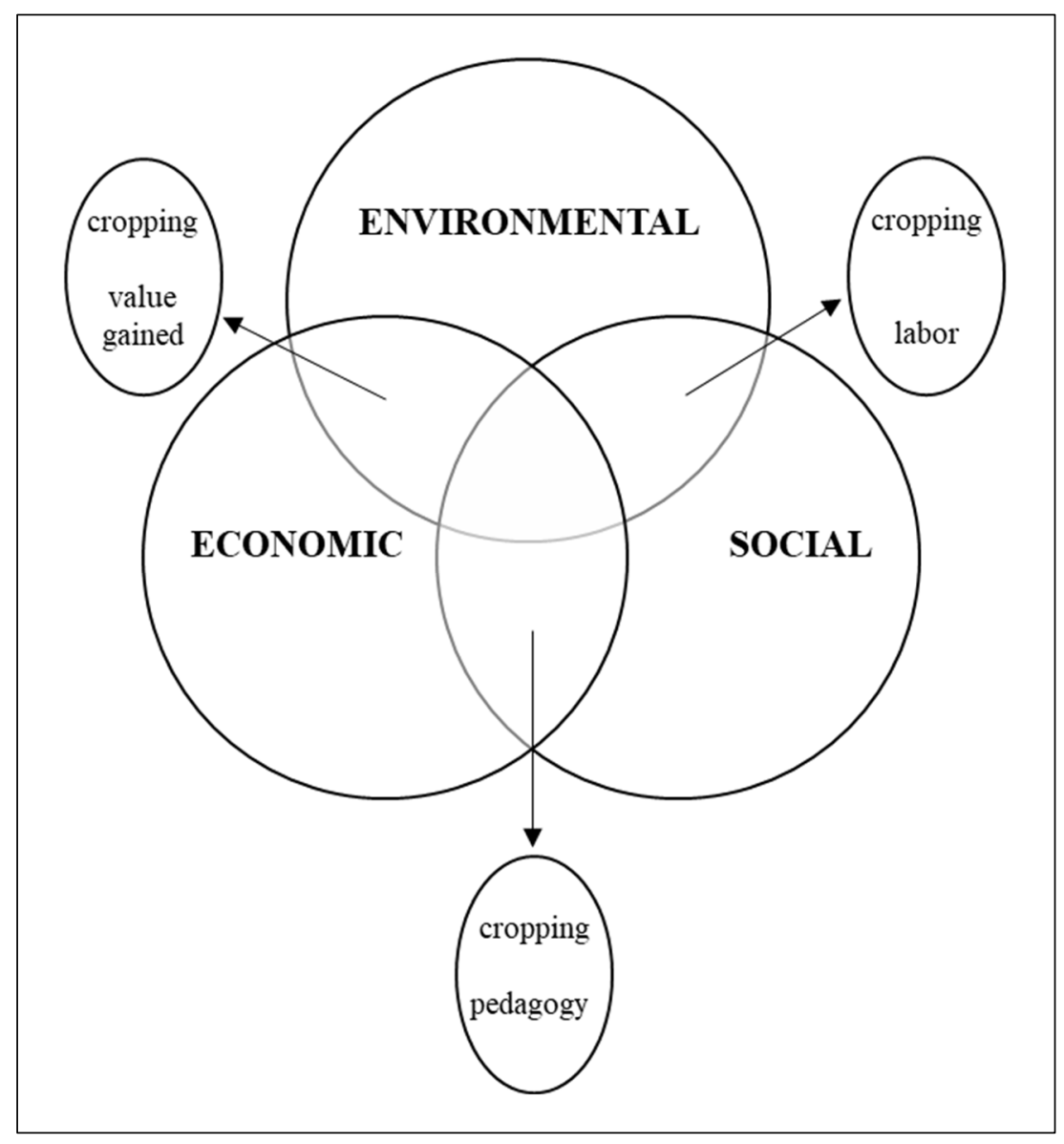

harvest a narrow set of crops so as to maximize sales to Dining Services and to serve the broadest student constituency. This raises an important question for the Farm's financial sustainability. Currently the Farm sells produce to Dining Services through an informal approach based on a relationship of mutual trust and shared interest. According to a study by Barlett (2017), a commitment to spend a portion of the food service budget on specific foods, or a metrics-based approach, would ensure continued purchasing. This approach, we argue, would maintain equitable access to the Farm's food, thereby validating the fairness involved by distributing the farm's bounty to all of the school's students. This raises the question: should the Farm codify an arrangement with Dining Services so that Dining Services commits to spending a portion of its budget on the Farm's produce (Barlett, 2017)?

Given that the stated raison d'être for many colleges and universities is their pedagogical mission, an assessment of a college farm's sustainability must include its contribution to the school's educational goals. We propose that this can be accomplished by comparing any financial operating losses to the cost of hiring teaching faculty. The cost of hiring faculty must, by definition, be less than the value gained. While Sayre (2011) found that younger college and university farms were more driven to attain financial selfsufficiency, long-term student farms were more likely to characterize student farms as educational resources that should not be expected to pay for themselves.

From the educational resource perspective, our findings encourage universities to measure the pedagogical value of campus farms instead of their financial costs. Even though our 
Farm operated under a financial independence model, we found in our course assessment that it was still able to positively affect the education of our students. We encourage colleges to not only look for potential curricular and extracurricular uses of campus farms, but also ways to evaluate these farms' contribution to those experiences. Effective assessment of an academic experience begins with knowing the desired learning outcomes (Bol \& Strage, 1996), as well as knowing the extent of the student-centeredness of the activities designed to help the students achieve those outcomes (Holt, Young, Keetch, Larsen, \& Mollner, 2015). As in our course assessment, one option would be to collect information about those learning outcomes and the farm-related activities to better understand the class-related value gained from campus farms (LaCharite, 2016). Similarly, the research goals and activities need to be understood to assess the pedagogical value of campus farmrelated research. Understanding the different educational and research potential of a campus farm will help schools as they consider integrating campus farms into their educational missions, creating or expanding farms, and, particularly, as they make the shift that Sayre (2011) emphasized, from focusing on narrow financial goals when they are relatively new to focusing on the economic value of pedagogical goals as they mature.

\section{Recommendations for Assessing the Sustainability of College Farms}

Our analysis indicates that the Farm at Davidson College is benign on most measures of sustainability. The Farm is strong in its educational contribution to sustainability; however, it needs continued improvement in the areas of the local food economy, labor practices, student food access, and tractor cultivation. Yet, in determining both the sustainability of the Farm and its value to the college, administrators have tended to focus on its financial independence (not its economic sustainability) as well as the value students, faculty, and staff place on its produce. We suggest that Davidson College, and other institutions with campus farms, may benefit from balancing these concerns with food justice and curricular goals. For example, campus farms should pay fair wages for farm personnel, provide equitable access to farm food for the student body, and facilitate educational experiences that equally integrate all three pillars of sustainability. These concerns lead us to reemphasize the importance of the social pillar of sustainability.

We conclude with the specific recommendations below for faculty, staff, and students who are interested in assessing the sustainability of their college farms. The first four points follow from our experience. The last five suggestions propose collaborations that would enhance the breadth of future analyses.

- Prepare, pre-test, and codify systems for data collection related to agricultural practices, including environmental, economic, and social indicators. We make this recommendation because we found it difficult to assess all the sustainability aspects from a post hoc perspective.

- Collaborate early and ensure buy-in from key stakeholders, including farm, dining services, physical plant, and student life personnel, and make data collection functional, easy, and of value to all parties. This recommendation is based on our success in working closely with faculty, staff, and students.

- Publicize the project often and widely to guarantee equitable access to participation. We make this recommendation in order to guarantee that all faculty, staff, and students who are interested in contributing to the campus farm feel welcome to participate.

- Create a framework and repository for student-directed research and data to prevent data loss and repetition of research. We make this recommendation based on our experience as faculty mentors to undergraduate research. This research is often not published or widely distributed but may be of value for institutional decision-making.

- Consult with education faculty and their students to create a framework for assessing the pedagogical value of the farm.

- Consult with environmental studies, biology, and chemistry faculty and their stu- 
dents on topics such as soil and water quality and wildlife surveys.

- Consult with economics faculty and their students on topics such as consumer and vendor surveys, extent of the market studies, etc., so as to assess the value of the farm instead of simply the financial flows.

- Consult with public health, anthropology, sociology, and psychology faculty and their students on topics such as food security, food access, food justice, food and culture, connections to nature, etc.

- Consult with history, gender, Indigenous, Latinx, Africana, and Asian studies faculty and their students to consider topics such as decolonization, social justice, and the histories of place and people of the specific farm landscape and the region.

While we necessarily focused on the context of the Davidson College Farm to answer our guiding question "is the college farm sustainable," we hope that our analytical template and the suggestions above develop the appropriate foundation for others to build upon our analysis and assess and enhance the sustainability of other campus farms. One lesson from this exercise is that faculty, staff, and students at schools with farms should view the inexactness of our conclusions as opportunities for more rigorous assessments of these farms in future research and engagement. For example, because of the value a farm's produce may bring to a college's dining services, questions arise such as: could a system be implemented for transferring additional funds from dining services to the farm? What financial requirements do dining services incur and would they want to extract payment from students for the additional value gained from eating a farm's produce? These questions go beyond the question of "if the university would pay a premium" to more fundamental questions of "should they pay a premium?" Regarding the local food economy, research on saturation and opportunity in the local food system as well as perceptions of college farms within the regional food system would be of value. Finally, we encourage administrators and faculty to holistically assess the sustainability of campus farms by exploring ways to compare and evaluate their operational losses alongside their educational contributions. We encourage administrators and faculty to ask: what educational value is gained from campus farms and how can that pedagogical value be compared with financial operating losses?

\section{References}

Aftandilian, D., \& Dart, L. (2013). Using garden-based service-learning to work toward food justice, better educate students, and strengthen campus-community ties. Journal of Community Engagement \& Scholarship, 6(1), 55-69.

Alkon, A. H., \& Agyeman, J. (2011). Cultivating food justice: Race, class, and sustainability. Cambridge, MA: MIT Press.

Allen, P., \& Kovach, M. (2000). The capitalist composition of organic: The potential of markets in fulfilling the promise of organic agriculture. Agriculture and Human Values, 17(3), 221-232. https://doi.org/10.1023/A:1007640506965

Allen, P., Van Dusen, D., Lundy, J., \& Gliessman, S. (1991). Integrating social, environmental, and economic issues in sustainable agriculture. American Journal of Alternative Agriculture, 6(1), 34-39. https://doi.org/10.1017/S0889189300003787

Altieri, M. A. (1988). Beyond agroecology: Making sustainable agriculture part of a political agenda. American Journal of Alternative Agriculture, 3(4), 142-143. https://doi.org/10.1017/S0889189300002411

Barlett, P. F. (2011). Campus sustainable food projects: Critique and engagement. American Anthropologist, 113(1), 101-115. https://doi.org/10.1111/i.1548-1433.2010.01309.x

Barlett, P. F. (2017). Campus alternative food projects and food service realities: Alternative strategies. Human Organization, 76(3), 189-203. https://doi.org/10.17730/0018-7259.76.3.189

Bol, L., \& Strage, A. (1996). The contradiction between teachers' instructional goals and their assessment practices in high school biology courses. Science Education, 80(2), 145-163. https://doi.org/10.1002/(SICI)1098-237X(199604)80:2<145::AID-SCE2>3.0.CO;2-G

Born, B., \& Purcell, M. (2006). Avoiding the local trap: Scale and food systems in planning research. Journal of Planning Education and Research, 26(2), 195-207. https://doi.org/10.1177/0739456X06291389 
Bruno, C. C., \& Campbell, B. L. (2016). Students' willingness to pay for more local, organic, non-GMO and general food options. Journal of Food Distribution Research, 47(3), 32-48. https://doi.org/10.22004/ag.econ.249998

Chollett, D. L. (2014). The Native American organic garden: Using service learning as a site of resistance. Culture, Agriculture, Food and Environment, 36(2), 93-104. https://doi.org/10.1111/cuag.12037

Coleman, E. (1989). The new organic grower: A master's manual of tools and techniques for the home and market gardener. White River Junction, VT: Chelsea Green.

Cooper, J. M., Butler, G., \& Leifert, C. (2011). Life cycle analysis of greenhouse gas emissions from organic and conventional food production systems, with and without bio-energy options. NJAS - Wageningen Journal of Life Sciences, 58(3-4), 185-192. https://doi.org/10.1016/j.njas.2011.05.002

Davidson College. (n.d.-a). The Farm at Davidson. Retrieved July 15, 2020, from https://www.davidson.edu/offices-and-services/farm-davidson

Davidson College. (n.d.-b). Financial aid. Retrieved from https://www.davidson.edu/admission-and-financial-aid/financial-aid

Davidson College Faculty Committee on Professional Affairs. (2017). Faculty salary report: Draft for the September 12, 2017 faculty meeting. Faculty Minutes Archives (RG 3/1.3 [Record Group 3, VPAA and Dean, Sub-Group 1 Dean, Subsub Group Faculty Minutes]). Davidson College, Davidson, NC.

Davidson College Human Resources. (n.d.). Student employment: Getting paid. Retrieved May 26, 2020, from https://www.davidson.edu/offices-and-services/human-resources/student-employment/getting-paid

DeLind, L. B. (2000). Transforming organic agriculture into industrial organic products: Reconsidering national organic standards. Human Organization, 59(2), 198-208. https://doi.org/10.17730/humo.59.2.hm8263678687n536

Department of City \& Regional Planning Master's Workshop. (2014). The state of low-wage work in North Carolina. Industry snapshot: Agriculture. The State of Low-Wage North Carolina. Retrieved from http://www.lowwagenc.org/snapshot-agriculture

Dubick, J., Mathews, B., \& Cady, C. (2016). Hunger on campus: The challenge of food insecurity for college students. Retrieved from https://studentsagainsthunger.org/hunger-on-campus/

Ehrenberg, R. G. (2012). American higher education in transition. Journal of Economic Perspectives, 26(1), $193-216$. https://doi.org/10.1257/jep.26.1.193

Elkington, J. (1998). Cannibals with forks: The triple bottom line of 21st century business. New Society Publishers.

Food and Agriculture Organization of the United Nations [FAO]. (2014). SAFA guidelines: Sustainability assessment of food and agriculture systems (Version 3.0). Food and Agriculture Organization of the United Nations. Retrieved from http://www.fao.org/nr/sustainability/sustainability-assessments-safa/en/

Frith, K. (2007). Is local more nutritious? It depends. Harvard School of Public Health Center for Climate, Health, and the Global Environment. Retrieved from https://iflahiff.wordpress.com/2011/02/25/is-local-more-nutritious-it-depends/

Galt, R. E., Parr, D., Van Soelen Kim, J., Beckett, J., Lickter, M., \& Ballard, H. (2013). Transformative food systems education in a land-grant college of agriculture: The importance of learner-centered inquiries. Agriculture and Human Values, 30(1), 129-142. https://doi.org/10.1007/s10460-012-9384-8

Gottlieb, R., \& Joshi, A. (2010). Food justice. Cambridge, MA: MIT Press. https://mitpress.mit.edu/books/food-justice

Gray, M. (2013). Labor and the locavore: The making of a comprehensive food ethic. University of California Press. https://www.ucpress.edu/book/9780520276697/labor-and-the-locavore

Green, A. (2021). A new understanding and appreciation for the marvel of growing things: Exploring the college farm's contribution to transformative learning. Food, Culture \& Society. https://www.tandfonline.com/toc/rffc20/current

Green, A., Hunt, G., \& Orner, C. (2018). Davidson College Farm CS A, research in progress. Davidson College, Department of Environmental Studies.

Guthman, J. (2004). Agrarian dreams: The paradox of organic farming in California. University of California Press.

Hamilton, K., \& Hekmat, S. (2018). Organic food and university students: A pilot study. Nutrition \& Food Science, 48(2), 218-227. https://doi.org/10.1108/NFS-06-2017-0127 
Henry, L. (2017). Understanding food insecurity among college students: Experience, motivation, and local solutions. Annals of Anthropological Practice, 41(1), 6-19. https://doi.org/10.1111/napa.12108

Hilimire, K., Gillon, S., McLaughlin, B. C., Dowd-Uribe, B., \& Monsen, K. L. (2014). Food for thought: Developing curricula for sustainable food systems education programs. Agroecology and Sustainable Food Systems, 38(6), $722-743$. https://doi.org/10.1080/21683565.2014.881456

Hinrichs, C. C. (2000). Embeddedness and local food systems: Notes on two types of direct agricultural market. Journal of Rural Studies, 16(3), 295-303. https://doi.org/10.1016/S0743-0167(99)00063-7

Hinrichs, C. C., Kloppenburg, J., Stevenson, S., Lezburg, S., Hendrickson, J., \& DeMaster, K. (1998). Moving beyond 'global' and 'local' (NE-185 working statement). https://web.archive.org/web/20081204045341/http://www.ces.ncsu.edu/depts/sociology/ne185/global.html

Holmes, S. M. (2013). Fresh fruit, broken bodies: Migrant farmworkers in the United States. University of California Press.

Holt, E. A., Young, C., Keetch, J., Larsen, S., \& Mollner, B. (2015). The greatest learning return on your pedagogical investment: Alignment, assessment or in-class instruction? PLOS ONE, 10(9), e0137446. https://doi.org/10.1371/journal.pone.0137446

Holthouser, D., \& Terry, R. (2012). Auxiliary food production operation at the McIntosh Farm (Memo to Ed Kania). Office of Finance and Administration Archives (RG 4/5.8 [Record Group 4, Vice President for Finance and Administration, Sub-Group 5 Auxiliary Services, Sub-sub Group 8 Farm]). Davidson College, Davidson, NC.

Hoover, B. M., \& MacDonald, L. (2017). Campus agriculture education: Educating food citizens or producers? Journal of Sustainability Education, 14. Retrieved from http://www.susted.com/wordpress/content/campus-agricultureeducation-educating-food-citizens-or-producers 2017 07/

Interagency Working Group on the Social Cost of Greenhouse Gases. (2016). Technical support document: Technical update of the social cost of carbon for regulatory impact analysis under Executive Order 12866. Retrieved from https://obamawhitehouse.archives.gov/sites/default/files/omb/assets/inforeg/technical-update-social-cost-ofcarbon-for-regulator-impact-analysis.pdf

Ireland, H. A., Sharpe, C. F. S., \& Eargle, D. H. (1939). Principles of gully erosion in the piedmont of South Carolina. Washington, D.C.: U.S. Department of Agriculture.

Jacobs, M. (1999). Sustainable development as a contested concept. In A. Dobson (Ed.), Fairness and futurity: Essays on environmental sustainability and social justice (pp. 21-45). Oxford University Press. https://doi.org/10.1093/0198294891.003.0002

Jaffee, D., \& Howard, P. H. (2010). Corporate cooptation of organic and fair trade standards. Agriculture and Human V alues, 27(4), 387-399. https://doi.org/10.1007/s10460-009-9231-8

Katt, F., \& Meixner, O. (2020). A systematic review of drivers influencing consumer willingness to pay for organic food. Trends in Food Science \& Technology, 100, 374-388. https://doi.org/10.1016/j.tifs.2020.04.029

Kleppel, G. S. (2014). The emergent agriculture: Farming, sustainability and the return of the local economy. Gabriola Island, BC: New Society Publishers.

Kramer, K. J., Moll, H. C., \& Nonhebel, S. (1999). Total greenhouse gas emissions related to the Dutch crop production system. Agriculture, Ecosystems \& Environment, 72(1), 9-16. https://doi.org/10.1016/S0167-8809(98)00158-3

LaCharite, K. (2016). Re-visioning agriculture in higher education: The role of campus agriculture initiatives in sustainability education. Agriculture and Human Values, 33(3), 521-535. https://doi.org/10.1007/s10460-015-9619-6

Lev, L., Hand, M. S., \& DiGiacomo, G. (2015). What does local deliver? In R. P. King, M. S. Hand, \& M. I. Gómez (Eds.), Growing local: Case studies on local food supply chains (pp. 291-2312). University of Nebraska Press.

Living Wage Calculator. (n.d.). Living wage calculation for Charlotte-Concord-Gastonia, NC. Retrieved May 29, 2020, from https://livingwage.mit.edu/metros/16740

Martinez, S., Hand, M., Pra, M. D., Pollack, S., Ralston, K., Smith, T., Vogel, S., Clark, S., Lohr, L., Low, S., \& Newman, C. (2010). Local food systems: Concepts, impacts, and issues (Economic Research Report No. 97). Retrieved from U.S. Department of Agriculture, Economic Research Service website https://www.ers.usda.gov/webdocs/publications/46393/7054 err97 1 .pdf?v $=42265$ 
Matteson, G. (2017). The nature of local food system farm businesses. In A. Dumont, D. Davis, J. Wascalus, T. Cheeks Wilson, J. Barham, \& D. Tropp (Eds.), Harvesting opportunity: The power of regional foods system investments to transform communities (pp. 139-150). Federal Reserve Bank of St. Louis \& Board of Governors of the Federal Reserve System. Retrieved from https://www.stlouisfed.org/community-development/publications/harvesting-opportunity

Meek, D., \& Tarlau, R. (2016). Critical food systems education (CFSE): Educating for food sovereignty. Agroecology and Sustainable Food Systems, 40(3), 237-260. https://doi.org/10.1080/21683565.2015.1130764

Montgomery, D. R. (2007). Soil erosion and agricultural sustainability. Proceedings of the National Academy of Sciences, 104(33), 13268-13272. https://doi.org/10.1073/pnas.0611508104

North Carolina Department of Labor. (n.d.). Minimum wage in N.C. Retrieved May 26, 2020, from https://www.labor.nc.gov/workplace-rights/employee-rights-regarding-time-worked-and-wages-earned/minimumwage-nc

Pirog, R. S., Van Pelt, T., Enshayan, K., \& Cook, E. (2001). Food, fuel, and freeways: An Iowa perspective on how far food travels, fuel usage, and greenhouse gas emissions. Leopold Center for Sustainable Agriculture Publications and Papers. https://lib.dr.iastate.edu/leopold pubspapers/3

Porter, C. M. (2018). Triple-rigorous storytelling: A PI's reflections on devising case study methods with five community-based food justice organizations. Journal of Agriculture, Food Systems, and Community Development, 8(A), 3761. https://doi.org/10.5304/jafscd.2018.08A.008

Pothukuchi, K. (2012). Building sustainable food systems in a single bottom-line context: Lessons from SEED Wayne, Wayne State University. Journal of Agriculture, Food Systems, and Community Development, 2(3), 103-119. https://doi.org/10.5304/jafscd.2012.023.011

Purcell, M., \& Brown, J. C. (2005). Against the local trap: Scale and the study of environment and development. Progress in Development Studies, 5(4), 279-297. https://doi.org/10.1191/1464993405ps122oa

Rodman, S. O., Barry, C. L., Clayton, M. L., Frattaroli, S., Neff, R. A., \& Rutkow, L. (2016). Agricultural exceptionalism at the state level: Characterization of wage and hour laws for U.S. farmworkers. Journal of Agriculture, Food Systems, and Community Development, 6(2), 89-110. https://doi.org/10.5304/jafscd.2016.062.013

Sayre, L. (2011). Introduction: The student farm movement in context. In L. Sayre \& S. Clark (Eds.), Fields of learning: The student farm movement in North America (pp. 1-28). Lexington: The University Press of Kentucky.

Silverthorn, D. (2016). Hungry for knowledge: Assessing the prevalence of student food insecurity on five Canadian campuses. Toronto: Meal Exchange. Retrieved from http://mealexchange.com

Spell, R. L., \& Johnson, B. G. (2019). Anthropogenic alluvial sediments in North Carolina Piedmont gullies indicate swift geomorphic response to 18th century land-use practices. Physical Geography, 40(6), 521-537. https://doi.org/10.1080/02723646.2019.1574145

Sutter, P. S. (2015). Let us now praise famous gullies. Athens: The University of Georgia Press.

Trimble, S. W. (1972). A volumetric estimate of man-induced erosion on the Southern Piedmont. In Present and prospective technology for predicting sediment yields and sources (pp. 142-154). USGS Agriculture Research Service Publications S-40.

Trimble, S. W. (2008). Man-induced soil erosion on the Piedmont. Soil and Water Conservation Society. http://www.swcs.org/resources/publications/man-induced-soil-erosion-on-the-piedmont-online

U.S. Department of Agriculture (USDA). (2017). Census of Agriculture-2017 State and County Profiles-North Carolina. Retrieved from USDA Agriculture Counts website: https://www.nass.usda.gov/Publications/AgCensus/2017/Online Resources/County Profiles/North Carolina/i ndex.php

U.S. Department of Labor. (2020). Fact Sheet \#12: Agricultural employers under the Fair Labor Standards Act (FLSA). Retrieved from U.S. Department of Labor Wage and Hour Division website: https://www.dol.gov/agencies/whd/fact-sheets/12-flsa-agriculture

Warren Wilson College Horse Crew. (2017, August 17). Celebrating horsepower at annual Plow Day. Warren Wilson College. https://www.warren-wilson.edu/2017/08/17/warren-wilson-college-celebrates-horsepower-annual-plow-day/ 
Weber, C. L., \& Matthews, H. S. (2008). Food-miles and the relative climate impacts of food choices in the United States. Environmental Science \&o Technology, 42(10), 3508-3513. https://doi.org/10.1021/es702969f

World Commission on Environment and Development. (1987). Our common future. Oxford University Press.

Yamashita, L., \& Robinson, D. (2016). Making visible the people who feed us: Educating for critical food literacy through multicultural texts. Journal of Agriculture, Food Systems, and Community Development, 6(2), 269-281. https://doi.org/10.5304/jafscd.2016.062.011

Yin, R. K. (2009). Case study research: Design and methods (4th ed.). Thousand Oaks, CA: SAGE. 